\title{
Aliocha Dostoevski's death during an epileptic seizure
}

\author{
Morte de Aliocha Dostoiévski durante uma crise epiléptica \\ Edson José Amâncio 1,2, Pedro André Kowacs³, Bruno Toshio Takeshita ${ }^{3}$, Fábio Augusto Nascimento 4 , Hélio \\ Afonso Ghizoni Teive ${ }^{5}$
}

\begin{abstract}
Mortality due to epilepsy is of great concern worldwide. Individuals with epilepsy have a two- or three-fold risk of death when compared to the general population. Based on biographical data and Anna Grigoriévna Dostoevskaia's memories, the authors concluded that a prolonged episode of status epilepticus was the culprit in the death of young Aliocha, youngest son of Fyodor Mikhailovich and Anna Dostoevski. At the time of Aliocha's death, very limited knowledge about epilepsy or therapeutic resources was available. Despite all the progress, epilepsies remain potentially fatal conditions. The suffering generated by Aliocha's death and other similar cases remains as a challenge for epileptologists who assemble efforts to fight against such conditions.
\end{abstract}

Keywords: epilepsy; Dostoevski; literature.

\section{RESUMO}

Mortalidade por epilepsia configura uma grande preocupação mundial com seus portadores apresentando um risco de morte de duas a três vezes maior do que a população em geral. Os autores concluem, segundo dados biográficos e as memórias de Anna Grigoryevna Dostoyevskaia, mãe de Aliocha, o filho mais novo de Fyodor Mikhailovich Dostoievski, que uma crise prolongada de "status epilepticus" tenha sido a causa da morte do jovem Aliocha. Na ocasião de sua morte, pouco conhecimento havia disponível quanto à epilepsia e aos recursos terapêuticos. Apesar de todo o progresso, as epilepsias permanecem como condições potencialmente fatais. 0 sofrimento gerado pela morte de Aliocha e outros casos similares continua a ser um desafio para que epileptologistas juntem esforços contra esta condição.

Palavras-chave: Epilepsia; Dostoievski; Literatura.

Mortality due to epilepsy is of great concern worldwide. Individuals with epilepsy have a two- or three-fold risk of death when compared to the general population. Extensive bibliography regarding to Dostoevski's epilepsy can be found in the literature ${ }^{1,2,3,4}$. Also, there is consensus that the Russian author called unwitting attention to knowledge about the epileptic aura of joy and pleasure, in his novel "The Idiot", with the description of seizures in the protagonist, Prince Mischkin.

This paper aims to revive the history of the death by epilepsy of Aliocha Dostoevski, the youngest son of the Russian writer, and to discuss this condition, as important as it was contemporaneous.

\section{THE DEATH OF ALIOCHA DOSTOEVSKI}

According to Joseph Frank ${ }^{4}$, who is probably the author of the most exhaustive biography of Dostoevski, Aliocha, the Russian's three-year-old son, died during an epileptic seizure:

"On April 30, 1878, his three-year-old son Aleksey (Aliocha) suffered a first epileptic convulsion of four minutes, that was taken as a childish symptom. On May 16, however, he was overcome by a major epileptic fit lasting for twelve hours and forty minutes, ending with his death."

\footnotetext{
${ }^{1}$ Universidade Federal do Triângulo Mineiro, Departamento de Neurocirurgia, Uberaba MG, Brasil;

${ }^{2}$ Universidade Lusíadas, Departamento de Neurocirurgia, Santos SP, Brasil;

${ }^{3}$ Instituto de Neurologia de Curitiba (INC), Departamento de Neurologia, Curitiba PR, Brasil;

4 University of Toronto, Toronto Western Hospital, Division of Neurology, Toronto, Ontário, Canadá;

5 Universidade Federal do Paraná, Departamento de Medicina Interna, Curitiba PR, Brasil.

Correspondence: Bruno Toshio Takeshita; Departamento de Neurologia, Instituto de Neurologia de Curitiba (INC); Rua Jeremias Maciel Perretto,

300; 81210-310 Curitiba PR, Brasil; E-mail: brunotakeshita@hotmail.com

Conflict of interest: There is no conflict of interest to declare.

Received 08 July 2016; Accept 16 August 2016
} 
Anna Grigoryévna Dostoevskaya, in her Memoirs of Anna Dostoyevskaya, also known as Reminiscence of Anna Dostoyevskaya or Dostoevski: Reminiscences ${ }^{5}$ (Figure 1) described that on May 16, 1878, her family suffered one more terrible tragedy, the death of her youngest son, Aliocha. Nothing foreshadowed this misfortune, since the boy was healthy and cheerful all the time. Even in the morning, on the day of his death, he babbled in their language, understandable to just a few, and was laughing out loud with the old woman, Prokhovna, who came to visit them before they left for Staraya, in Russia. Suddenly, Aliocha's face began to tremble and convulse. The babysitter thought it was normal in children when teeth are errupting - at this exact time his molars were beginning to appear. However, Anna panicked and called their pediatrician, Dr. A. Tchochin, who lived nearby. Apparently, he did not give a lot of significance to the disease, prescribed some simple medicine and stated that the seizures would soon be gone. But as seizures did not cease, Anna woke up Fyodor Mikhailovich (Dostoevski) (Figure 2), who became very worried. They decided to consult an expert on neurological diseases and went to see Dr. Uspenski. He was busy at the time with 20 people in the waiting room. He welcomed them and said that as soon as he had finished the consultations he would come to their house. He prescribed a tranquilizer and asked for an oxygen mask to help the child breathe. When they got home, they found their poor boy in the same state: unconscious and shaking with convulsions. Apparently Aliocha was not suffering, as no moaning or screaming was heard. They moved away from their little boy and impatiently waited for the doctor. He arrived about two hours later and examined the

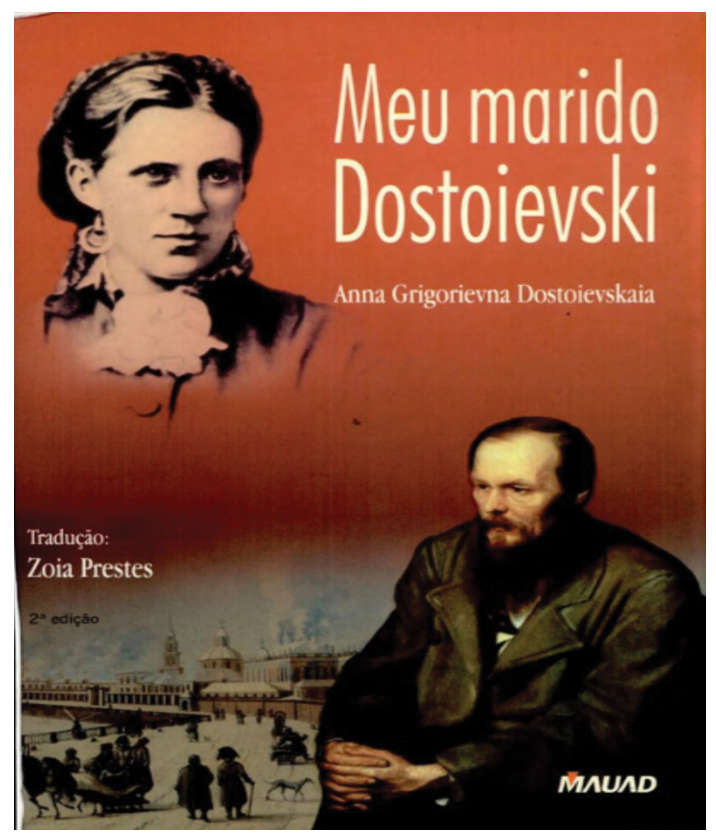

Figure 1. Book cover. Dostoievskaia AG. Dostoiévski, Meu Marido. Tradução Zoia Prestes, Balneário Camboriú:Ed. Mauad patient, saying that there was no need to cry or to be worried as the convulsions would soon be gone. Dostoevski went out with the doctor, and came back pale and knelt in front of the couch, where the boy was laying. Anna knelt down beside her husband and wanted to ask what the doctor said - afterwards she was told that the doctor had told Dostoevski that the boy was already dying, but he was forbidden to tell her. After about an hour, they realized that the seizures were ceasing. Reassured by the doctor, Anna was relieved, feeling that the shaking had turned into sound sleeping, perhaps announcing his recovery. But to her despair the boy stopped breathing and died. Fyodor Mikhailovich kissed the boy, blessed him with the sign of the cross three times and burst into tears. The father was deeply shaken by this loss, and more distressed because the boy had died of epilepsy, a disease supposedly inherited from him.

\section{DISCUSSION}

\section{Mortality in epilepsy}

There are few papers on the natural history of untreated epilepsy and/or convulsive status epilepticus. Aminoff and Simon reported on the outcome of convulsive status epilepticus in 98 patients older than 14 years, and found that the condition was fatal in 28 cases, and that most deaths were related to the underlying etiology ${ }^{6}$. However, two patients died shortly after the status epilepticus, in a situation akin the one that victimized Aliocha. A comprehensive review on the outcome of pediatric convulsive status epilepticus found short-term mortality after convulsive status epilepticus to be $2.7-5.2 \%$ and also leaned toward this etiology as being the main determinant of death. However, in Aliocha's case, the etiology was not identified and contrary to his father's misconception that his son had inherited epilepsy from him. Genetic epilepsies with age-related onset are seldom fatal ${ }^{7}$. Indeed, a solid aggravating factor was the duration of Aliocha's

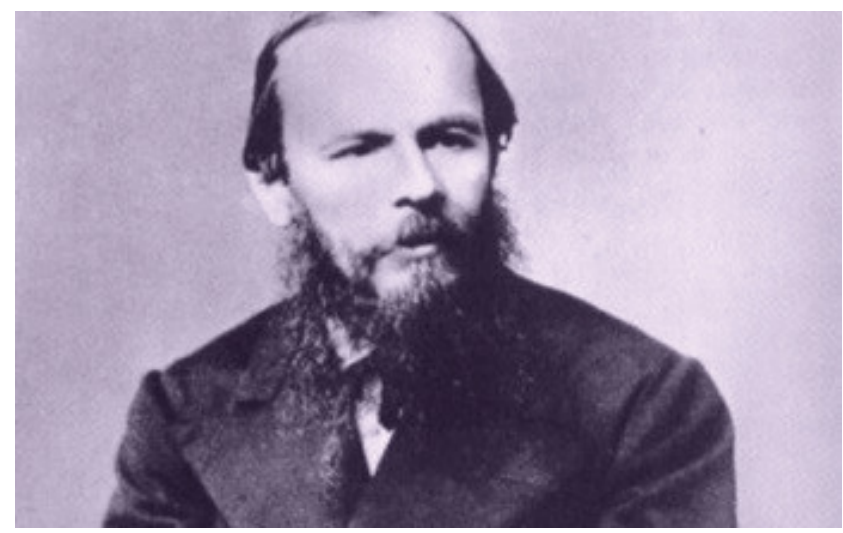

Figure 2. Fyodor Mikhailovich Dostoevski, the writer. 
convulsive status epilepticus, since a duration longer than one hour may be associated with a higher mortality.

A speculation on the etiology of Aliocha's status epilepticus is the possibility of a febrile infection-related epilepsy syndrome, which presents with a sudden onset, is potentially fatal, and most often affects previously-healthy individuals between three and 15 years old ${ }^{8}$. Another hypothesis would be the Rasmussen syndrome, which affects the young, with sudden onset, although this most often has a slower course. Metabolic and autoimmune disorders are also possible diagnoses ${ }^{8}$, but there was no previous evidence of associated symptoms.

At the time of Aliocha's death, none of this knowledge was available. The medicines, which began to be used in the 19th and 20th century, were bromide in 1857 by Locock and barbiturates in 1912 by Hauptmann'. The pain and the suffering generated by Aliocha's death and other similar cases were, and still are, a challenge for epileptologists who garner their efforts to fight against such conditions.

\section{References}

1. Gastaut H. Fyodor Mikhailovitch Dostoevsky's involuntary contribution to the sympotomatology and prognosis of epilepsy. William G. Lennox Lecture, 1977. Epilepsia. 1978;19(2):186-201. doi:10.1111/j.1528-1157.1978.tb05030.x

2. Alajouanine T. Dostoiewski's epilepsy. Brain. 1963;86(2):210-8. doi:10.1093/brain/86.2.209

3. de Souza LC, Mendes MF. [Prince Liev Nikoláievitch Míchkin ("The Idiot", Fiódor Dostoevsky) and the interictal personality syndrome of temporal lobe epilepsy]. Arq Neuropsiquiatr. 2004;62(2B):558-64. doi:10.1590/S0004-282X2004000300036

4. Frank J. Dostoiévski. O manto do profeta,1871-1881. São Paulo: Edusp; 2007. p. 480-1.

5. Dostoievskaia AG. Dostoiévski, Meu Marido. Tradução Zoia Prestes, Balneário Camboriú:Ed. Mauad, 1999:262-263
6. Aminoff MJ, Simon RP. Status epilepticus: causes, clinical features and consequences in 98 patients. Am J Med. 1980;69(5):657-66. doi:10.1016/0002-9343(80)90415-5

7. Nevalainen O, Ansakorpi H, Simola M, Raitanen J, Isojärvi J, Artama M et al. Epilepsy-related clinical characteristics and mortality: a systematic review and meta-analysis. Neurology. 2014;83(21):1968-77. doi 10.1212/WNL.0000000000001005

8. Varadkar S, Cross JH. Rasmussen syndrome and other inflammatory epilepsies. Semin Neurol. 2015;35(3):259-68. doi:10.1055/s-0035-1552921

9. Masia SL, Devinsky O. Epilepsy and behavior: a brief history. Epilepsy Behav. 2000;1(1):27-36. doi:10.1055/s-0035-15529210.1006/ebeh.1999.0021 


\section{Erratum}

Refractory epilepsy in children with brain tumors. The urgency of neurosurgery.

Arq Neuropsiquiatr 2016;74(12):1008-1013. DOI: 10.1590/0004-282X20160157

\section{The authors:}

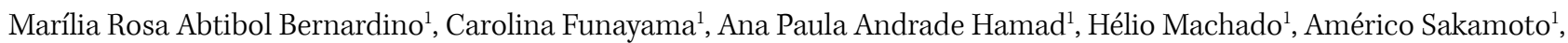
Ursula Thome ${ }^{1}$, Vera Cristina Terra ${ }^{1}$, Antonio Carlos dos Santos ${ }^{1,2,3}$

\section{Should be:}

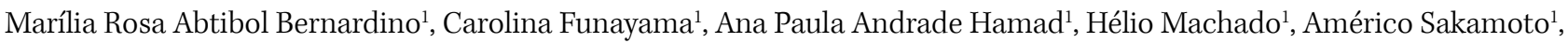
Ursula Thome ${ }^{1}$, Vera CristinaTerra ${ }^{1}$, Antonio Carlos dos Santos ${ }^{1,2,3}$, Luciano Nader Serafani ${ }^{4}$, Nathalia Cunha Calixto ${ }^{2}$, Huria Shalom Monturil de Carvalho Silva ${ }^{4}$

\section{The afiliations:}

${ }^{1}$ Universidade de São Paulo, Faculdade de Medicina de Ribeirão Preto, Departamento de Neurociências e Ciências do Comportamento, Ribeirão Preto SP, Brasil;

${ }^{2}$ Universidade de São Paulo, Faculdade de Medicina de Ribeirão Preto, Departamento de Neuroradiologia, Seção de Ressonância Magnética, Ribeirão Preto SP, Brasil;

${ }^{3}$ Universidade de São Paulo, Faculdade de Medicina de Ribeirão Preto, Hospital das Clínicas, Centro de Ciências das Imagens e Física Médica, Ribeirão Preto SP, Brasil.

\section{Should be:}

${ }^{1}$ Universidade de São Paulo, Faculdade de Medicina de Ribeirão Preto, Departamento de Neurociências e Ciências do Comportamento, Ribeirão Preto SP, Brasil;

${ }^{2}$ Universidade de São Paulo, Faculdade de Medicina de Ribeirão Preto, Departamento de Neuroradiologia, Seção de Ressonância Magnética, Ribeirão Preto SP, Brasil;

${ }^{3}$ Universidade de São Paulo, Faculdade de Medicina de Ribeirão Preto, Hospital das Clínicas, Centro de Ciências das Imagens e Física Médica, Ribeirão Preto SP, Brasil;

${ }^{4}$ Universidade de São Paulo, Faculdade de Medicina de Ribeirão Preto, Departamento de Patologia e Medicina Legal, Ribeirão Preto SP, Brasil.

Aliocha Dostoevski's death during an epileptic seizure.

Arq Neuropsiquiatr 2016; 74 (11): 944-946. DOI: 10.1590/0004-282x20160147

\section{The paragraph:}

However, Anna panicked and called their pediatrician, Dr. A. Tchochin, who lived nearby, picked up the phone immediately. (Page 945)

\section{Should be:}

However, Anna panicked and called their pediatrician, Dr. A. Tchochin, who lived nearby.

\section{Fat embolism showing restriction on diffusion sequence in brain magnetic resonance imaging.}

Arq Neuropsiquiatr 2016;74(7):597-598. DOI: http://dx.doi.org/10.1590/0004-282X20160052

\section{The authors:}

Henry Koiti Sato ${ }^{1}$, Pedro André Kowacs ${ }^{1}$, Josep Dalmau², Paulo Sergio Faro Santos ${ }^{2}$

\section{Should be:}

Henry Koiti Sato ${ }^{1}$, Pedro André Kowacs ${ }^{1}$, Paulo Sergio Faro Santos ${ }^{1}$

The afiliation "'Universitat de Barcelona, Institut D’Investigacions Biomédiques August Pi I Sunyer, Hospital Clínic, Barcelona, Spain." must be ignored. 